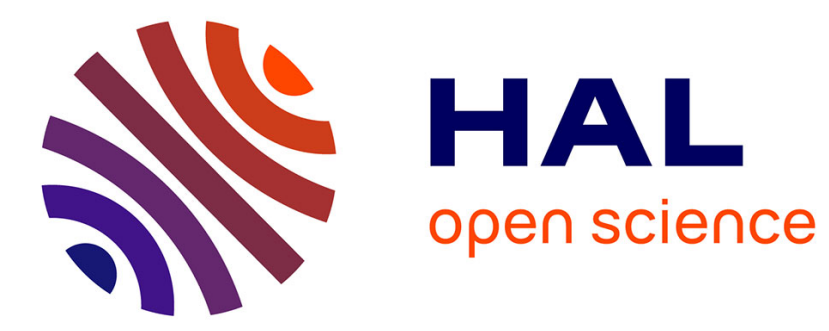

\title{
Voltammetry of MicroParticles in Thin Layer
}

Michel Perdicakis, Quan Qin, Maria Bertucci, Hugues Aubriet

\section{To cite this version:}

Michel Perdicakis, Quan Qin, Maria Bertucci, Hugues Aubriet. Voltammetry of MicroParticles in Thin Layer. Electrochimica Acta, 2016, 193, pp.172-179. 10.1016/j.electacta.2016.01.209 . hal-01507493

\section{HAL Id: hal-01507493 \\ https://hal.univ-lorraine.fr/hal-01507493}

Submitted on 4 Jul 2018

HAL is a multi-disciplinary open access archive for the deposit and dissemination of scientific research documents, whether they are published or not. The documents may come from teaching and research institutions in France or abroad, or from public or private research centers.
L'archive ouverte pluridisciplinaire HAL, est destinée au dépôt et à la diffusion de documents scientifiques de niveau recherche, publiés ou non, émanant des établissements d'enseignement et de recherche français ou étrangers, des laboratoires publics ou privés. 


\section{Voltammetry of MicroParticles in Thin Layer}

This document is a post print. Final version has been published in Electrochimica Acta

Volume 193, 1 March 2016, Pages 172-179, doi.org/10.1016/j.electacta.2016.01.209

Abstract: We describe a new experimental device for the characterization of electroactive microparticles and of the soluble species released during their electrochemical transformation. By using only a few microparticles, it provides, in a faster way, similar information as modified carbon paste electrodes with electrolytic binders (CPEEBs) and the sensitivity and resolution are must better. The device geometry was modelled with ferrocyanide ions and the voltammograms for ferrocene, pyrolusite and hematite were compared with the literature ones concerning CPEEBs. Finally, an alumina-supported palladium catalyst and pyrite-containing argillite were successfully characterized.

Keywords: Voltammetry of microparticles, Manganese dioxide, Ferric oxide, Alumina supported palladium, Callovo-Oxfordian argillite

\section{Introduction}

Voltammetry of microparticles (VMP) is a technique developed by Scholz [1] that can be applied for the voltammetric characterization of any solid electroactive material, conducting 
or not, via the mechanical immobilization of microparticles on the cross section of a current

2 collector [2-5]. This latter is most often a graphite rod which had been previously impregnated with solid paraffin to fill up the graphite pores. VMP has the advantages over carbon paste

14
electroactive electrodes of requiring only a few micrograms of matter to be analyzed and avoiding the use of organic binders that can influence the electrochemical behaviour of the solid compounds. However, VMP cannot provide information on the soluble species released in solution by the immobilized microparticles during their electrochemical transformation. when the electrochemical kinetics is slow and voltammetry at rapid scan rates is inoperable. To get this information today, electrochemists can utilize Carbon Paste Electrodes with Electrolytic Binders (CPEEBs), which have been developed in the seventies by the Bauer group who established a theoretical model on their working principle [6-8]. CPEEBs are prepared by mixing graphite powder with electrolytic solutions instead of non-conducting pasting liquids with traditional modified carbon paste electrodes [9]. In this way, in principle, the whole of the electroactive matter inserted in the carbon paste is electrochemically transformed and soluble species released are trapped in the carbon paste. These electrodes have been successfully used with various compounds just as well insoluble (ferrocene [6], uranium ores [11] copper sulphides [12-14], ilmenites [15], oxides of iron [16-21], copper [21] and manganese [22]) as dissolved directly in the electrolyte $\left(\mathrm{FeCl}_{2}\right.$ and $\mathrm{MnCl}_{2}$ [22], $\mathrm{Fe}(\mathrm{CN})_{6}{ }^{4-}$ and $\left.\mathrm{O}_{2}[6]\right)$. Ramirez et al. proposed some experimental modifications [23] and the Vittori group introduced theoretical complements on the Bauer model [24,25]. Nevertheless, when CPEEBs are employed, extremely slow scan rates (in the range of some hundredths or tenths of $\mathrm{mV} / \mathrm{s}$ ) and very concentrated supporting electrolytes are used in order to minimize capacitive currents. Moreover, the effective deaeration of the carbon paste is quite hard (use of vacuum and glove boxes or previous electrochemical reduction of atmospheric oxygen if possible). In addition, if the solubilization of the non-conducting electroactive microparticles

\footnotetext{
${ }^{1}$ ISE membre
} 
is very slow, the faradaic current becomes of the same order of magnitude as the background

\section{Experimental}

\subsection{The electrochemical cell}

Experimental setup: some electroactive microparticles and a TL of solution are entrapped 
between the cross sections of two graphite rods. The rods are mounted, with an epoxy resin

2 (Epofix kit from Struers), in the axis of the truncated plungers of two glass syringes that allow to the rods to slide hermetically inside the end truncated syringe barrels (Fig. 1A). The rods are externally short-circuited and connected to the working electrode input of the potentiostat. The main purpose of using two short-circuited graphite electrodes opposite each other instead 6 of only one against an insulating surface, as with classic thin layer cells, is to ensure a good electrical contact with the immobilized electroactive microparticles allowing the electrochemical transformation of the greatest possible number, if not all, of them.

Before mounting the graphite rods $(3.05 \mathrm{~mm}$ diameter, $99.9995 \%$ metals basis from Alfa Aesar) in the truncated plungers of the syringes it is necessary to fill up the graphite pores with solid paraffin to eliminate the electrochemical response of adsorbed oxygen and to avoid the contamination of graphite by soluble species as recommended by Scholz [1].

Cell design: the cell, depicted schematically in Figure 1B, is made of Perspex and has a cylindrical shape. There is a central cylindrical conduit, containing the electrolytic medium, where are stuck horizontally with a bicomponent epoxy glue the syringe barrels where the two graphite electrodes are allowed to move. A platinum counter electrode inserted in a PTFE stopper is screwed on the basis of the cell and, according to the experiment, a silver-wire used as the quasi-reference electrode or a $\mathrm{Ag} / \mathrm{AgCl}$ reference electrode are inserted in a PTFE stopper on the top of the cell. An inert gas inlet tube is also inserted in the top stopper. Depending on the position of the tube, the gas is bubbling through the solution or it maintains an inert atmosphere over its surface. The device is equipped with a metallic holder and a slight rotation about its axis allows to remove one after the other the graphite electrodes for cleaning or polishing without emptying the cell.

\subsection{Use of the device}

To transfer and immobilize the electroactive particles inside the TL, a few grains are applied 
to the graphite surface of one of the electrodes and pressed on it with a small spatula. Then the paper or with a grinding paper, if necessary.

\subsection{Electrochemical measurements}

\subsection{Chemicals and minerals} ('GeoRessources' laboratory - Université de Lorraine). electrode is softly struck against a glass surface before its introduction in the electrochemical cell in order to remove the particles that were badly fixed. After deaeration of the solution, the graphite electrodes are pushed up and rotated one against the other in such a way that the immobilized microparticles come in the most intimate contact with the two graphite discs.

Before each experiment the surface of the electrodes is cleaned by polishing with a filter

Voltammetric experiments were performed with a model 174A polarographic analyzer (EG\&G-PAR), which was interfaced via a computer AD card and monitored by a home-made application created by means of the TestPoint ${ }^{\mathrm{TM}}$ software, or with a 'Quadstat' four-channel potentiostat used as a single three-electrode potentiostat and monitored by the EChem Software (both from EDaq). According to the experiments, the potentials were referred to the silver quasi-reference electrode $(\mathrm{Ag} / \mathrm{QREF})$ or to the saturated $\mathrm{Ag} / \mathrm{AgCl}$ electrode.

Potassium hexacyanoferrate(II), sulphuric and hydrochloric acids and potassium chloride, were of RP Normapur grade from Prolabo. Ferrocene purum grade, manganese(IV) oxide puriss. grade and iron(III) oxide puriss. p.a. grade were obtained from Fluka, and palladium(II) chloride from Merck. Palladium on alumina pellets loading 5 wt. \% catalyst was from Johnson Matthey (see SECM characterization in Fig. 2A). The Callovo-Oxfordian argillite sample containing 0.5-1 wt. \% pyrite [30] came from Bure (Meuse) in France (optical microscope picture in Fig. 2B). It was kindly provided by Prof. M. Cathelineau 


\section{Results and Discussion}

\subsection{Test of the device with the $\mathrm{Fe}(\mathrm{CN}) 6^{3-} / \mathrm{Fe}(\mathrm{CN}) 6^{4-}$ system}

A series of cyclic voltammograms obtained for $2 \mathrm{mM} \mathrm{K}_{4} \mathrm{Fe}(\mathrm{CN})_{6}$ in $1 \mathrm{M} \mathrm{KCl}$ using scan rates

from 1 to $5000 \mathrm{mV} / \mathrm{s}$ allowed us to estimate the liquid TL thickness. Some typical voltammograms recorded in the $10-100 \mathrm{mV} / \mathrm{s}$ range are displayed in Figure 3A. The analysis of the results shows that the anodic and cathodic peak separation $\left(\Delta E_{p}\right)$ first decreases until the scan rate $(v)$ is over $6 \mathrm{mV} / \mathrm{s}$ then increases (Fig. 3B). $\Delta E_{p}$ remains smaller than $58 \mathrm{mV}$ as long as $v$ is lower than $40 \mathrm{mV} / \mathrm{s}$. The plot of the anodic peak current $\left(I_{p}\right)$ versus $v$ in a log-log representation (Fig. 3C) exhibits two linear parts with an interconnecting break point at about $100 \mathrm{mV} / \mathrm{s}$. The slope of the first part, very close to 1, indicates a TL behaviour, $I_{p}=\left[n^{2} \mathrm{~F}^{2} V C^{\circ} /(4 \mathrm{R} T)\right] v(1)$. The second part has a slope very close to 0.5 according to the cyclic voltammetry theory: $I_{p}=\left[0.4463\left(\mathrm{~F}^{3} /[\mathrm{R} T]\right)^{1 / 2} n^{3 / 2} A D^{1 / 2} C^{\circ}\right] v^{1 / 2}(2)$. In these formulas, $C^{\circ}$ and $D$ are, respectively, the concentration and the diffusion coefficient of the electroactive species, $V$ the volume of the TL and $A$ the surface area of the electrode. The variation of the slope of $\log I_{p}$ vs. $\log v$ is interpreted as follows: As long as the diffusion layer thickness remains wider than the distance between the graphite electrodes one observe a TL behaviour. Then, when $v$ becomes high enough for the diffusion layer to become smaller than the TL, the system varies with $v$ according to the cyclic voltammetry theory. The scan rate value at the break point $\left(v_{\mathrm{bp}}\right)$ depends only on the TL thickness $(l)$ and $D$. In fact, at this point, $I_{p}$ can be calculated by both equations (1) and (2) and one can easily demonstrate that $l=$ $1.7852\left[D \mathrm{R} T /\left(n \mathrm{~F} v_{\mathrm{bp}}\right)\right]^{1 / 2}$ (3). According to the experimental data, $v_{\mathrm{bp}}=96 \mathrm{mV} / \mathrm{s}$ that gives 24.6 $\mu \mathrm{m}$ for $l$. As the VMPTL device comprises two parallel active graphite electrodes, $l$ must be multiplied by 2 to have the real interelectrode distance, therefore, the distance is about $50 \mu \mathrm{m}$. Figure $4 \mathrm{C}$ also shows the modelling made using equations (1) and (2) with $D_{\mathrm{Fe}(\mathrm{CN})_{6}^{4-}}=$ $7.4 \times 10^{-6} \mathrm{~cm}^{2} / \mathrm{s}$ [31] for two $3.0 \mathrm{~mm}$ diameter electrodes put in front each other and forming 
two $24.6 \mu \mathrm{m}$ TLs; the calculated curve is in good agreement with the experimental points.

\subsection{Comparison with literature experiments performed with CPEEBs}

In this section the voltammograms recorded for ferrocene, pyrolusite and hematite using VMPTL are compared with those obtained by Bauer et al. [6] and Lorenzo et al. [21,22] with

CPEEBs. Four i-E curves from these references have been digitized and superimposed on our own experimental data to aid comparison.

\subsubsection{Characterization of ferrocene}

Ferrocene has been used in the very first experiments performed with CPEEBs in the seventies by the Bauer group. Voltammograms for ferrocene microparticles recorded in $1.4 \mathrm{M}$ $\mathrm{H}_{2} \mathrm{SO}_{4}$ using VMPTL, at $2 \mathrm{mV} / \mathrm{s}$, and a CPEEB at $0.2 \mathrm{mV} / \mathrm{s}$ (from ref. [6]) are shown in Figure 4A. Overall, the shape of the two curves are quite comparable in spite of a scan rate 10 times faster for VMPTL. At the first anodic scan, started from the open circuit potential (OCP), the oxidation of ferrocene is spread over several hundreds of millivolts because of the ohmic drop resulting from the bad contact between the insulating ferrocene particles and graphite. In contrast, the reduction of the produced soluble ferrocenium cation gives rise to the symmetrical cathodic peak $\mathrm{C} 1$ at potentials close to the thermodynamic value. The second anodic scan is much less affected by ohmic drop because of the intimate contact between graphite and the ferrocene deposited on it during the reduction of $\mathrm{Fc}^{+}$at $\mathrm{C} 1$. However, in the case of CPEEB, peak A1 is far from being symmetrical because of remaining ohmic drop. Some typical cyclic voltammograms recorded with the VMPTL device after stabilization of the currents are displayed in Figure 4B. Thus, in the case of ferrocene, VMPTL provides more rapidly similar information to the one obtained using CPEEBs and the corresponding voltammograms are less affected by ohmic drop. 


\subsubsection{Characterization of pyrolusite}

2 The voltammogram recorded with $\mathrm{MnO}_{2}$ microparticles in $10 \mathrm{mM} \mathrm{HCl}$ using VMPTL at 5 $\mathrm{mV} / \mathrm{s}$ and that displayed in ref. [22] (CPEEB, $v=0.5 \mathrm{mV} / \mathrm{s}$ ) are represented in Figure 5. The scans were started from the OCP in the negative direction. Both voltammograms provide similar information, however, the voltammogram recorded using VMPTL does not suffer neither from ohmic drop nor from capacitive current as that using CPEEB, in spite of a scan rate ten times faster.

According to Lorenzo et al. [22], the cathodic peak $\mathrm{C} 1^{\circ}$, observed at the first cycle, corresponds to the reduction of the initial $\mathrm{MnO}_{2}$ in soluble $\mathrm{Mn}^{2+}$ ions $\left(\mathrm{MnO}_{2}+4 \mathrm{H}^{+}+2 \mathrm{e}^{-} \rightarrow\right.$ $\left.\mathrm{Mn}^{2+}+2 \mathrm{H}_{2} \mathrm{O}\right)$. After the scan reversal, the opposite reaction occurs at anodic peak A1, which is located just before the anodic limit. After another reversal of the sweep direction, the cathodic signal for the reduction of $\mathrm{MnO}_{2}$ electrochemically deposited on the graphite surface (peak $\mathrm{C} 1$ ) is shifted towards more positive potentials with respect to peak $\mathrm{C} 1^{\circ}$. A careful examination of the voltammogram obtained with VMPTL shows that: (i) The $\mathrm{C} 1 / \mathrm{C} 1^{\circ}$ peaks area ratio is about 1.1 (This ratio is approximately 2.6 in the case of the CPEEB because of the presence of $\mathrm{Mn}^{2+}$ ions in the electrolyte inside the carbon paste. According to the authors, $\mathrm{Mn}^{2+}$ result from the interaction of $\mathrm{MnO}_{2}$ with $\mathrm{HCl}$, however, the corresponding chemical reaction is not written and the process is unclear for us). (ii) In the VMPTL voltammogram, a very slight signal is still present at $\mathrm{C}^{\circ}$ during the second cycle that means that the $\mathrm{MnO}_{2}$ reduction is not totally complete. When a CPEEB is used, it is very difficult to estimate the amount of $\mathrm{MnO}_{2}$ reduction at the second scan because of the probable overlapping of peaks $\mathrm{C} 1^{\circ}$ and $\mathrm{C} 1$.

\subsubsection{Characterization of hematite}

The voltammogram for the characterization of $\mathrm{Fe}_{2} \mathrm{O}_{3}$ in $1 \mathrm{M} \mathrm{KCl}$ at $\mathrm{pH} 1$ using VMPTL is shown in Figure 6A (curve a). The potential scan $(v=5 \mathrm{mV} / \mathrm{s})$ started from the OCP in the 
negative direction. The cathodic peak $\mathrm{C}^{\circ}$ corresponds to the $\mathrm{Fe}_{2} \mathrm{O}_{3}$ reduction into $\mathrm{Fe}^{2+}$ that is

2 oxidized to $\mathrm{Fe}^{3+}$ during the reverse scan (peak A1). Along the second and next cycles $\mathrm{Fe}^{3+}$ is reduced in $\mathrm{Fe}^{2+}(\mathrm{C} 1)$ and then oxidized again in $\mathrm{Fe}^{3+}$ (A1). This voltammogram closely resembles that obtained by Encinas Bachiller et al. [21] in $1 \mathrm{M} \mathrm{HCl}$ by means of a CPEEB at $0.5 \mathrm{mV} / \mathrm{s}$. However, in the case of VMPTL, because of the lower acidity of the solution, the 6 reduction of $\mathrm{Fe}_{2} \mathrm{O}_{3}$ takes place at more negative potentials and the peak shape for the $\mathrm{Fe}^{3+}$ 2 $^{2+}$ system is different. Indeed, peaks A1 and C1 related do CPEEB demonstrates pure TL behaviour but are not symmetrical because of the ohmic drop, whereas those related to VMPTL are almost symmetrical. Moreover, even if peaks A1 on both voltammograms are virtually superimposable, the A1-C1 peak separation is larger in the case of VMPTL because of the formation of $\mathrm{FeOH}^{2+}$ and $\mathrm{Fe}(\mathrm{OH})_{2}{ }^{2+}$ species whose reduction is more difficult than that of $\mathrm{Fe}^{3+}[32]$.

Figure 6B illustrates the comparison of the voltammograms for $\mathrm{Fe}_{2} \mathrm{O}_{3}$ recorded with VMPTL $(v=5 \mathrm{mV} / \mathrm{s})$ and CPEEB $(v=0.5 \mathrm{mV} / \mathrm{s}$, from ref. [22] $)$ in the same medium: $10 \mathrm{mM} \mathrm{HCl}$. As in the case of $\mathrm{MnO}_{2}$, the voltammogram corresponding to VMPTL shows no ohmic drop nor capacitive current if compared to that for CPEEB. However, the two voltammograms are completely different. The one for CPEEB provides similar information as provided in the $1 \mathrm{M}$ $\mathrm{HCl}$ medium. When VMPTL is used, the $\mathrm{Fe}_{2} \mathrm{O}_{3}$ reduction is far to be complete, the signal A1 for $\mathrm{Fe}^{2+}$ oxidation is flat while that for $\mathrm{Fe}^{3+}$ reduction $(\mathrm{C} 1)$ is barely visible. This due to the very low quantity of protons inside the TL. Indeed, the electrochemical reduction of hematite according to the reaction: $\mathrm{Fe}_{2} \mathrm{O}_{3}+2 \mathrm{e}^{-}+6 \mathrm{H}^{+} \rightarrow 2 \mathrm{Fe}^{2+}+3 \mathrm{H}_{2} \mathrm{O}(1)$ requires 2 electrons and 6 protons.

Indeed, assuming that in the best-case scenario the TL thickness is $100 \mu \mathrm{m}$, the corresponding TL volume is $7 \times 10^{-7} \mathrm{~L}$, which contains $7 \times 10^{-9} \mathrm{~mol}$ of protons. By integration of the voltammetric curve in Figure $6 \mathrm{~B}$, we estimated at approximately $4.3 \times 10^{-4} \mathrm{C}$ the charge 
exchanged at peak $\mathrm{C}^{\circ}$ and, consequently, the reduction concerns $2.2 \times 10^{-9}$ mol of $\mathrm{Fe}_{2} \mathrm{O}_{3}$ that require $1.3 \times 10^{-8} \mathrm{~mol}$ of $\mathrm{H}^{+}$. Yet, only $7 \times 10^{-9} \mathrm{~mol}$ are present in the TL. In this way, the $\mathrm{pH}$ inside the TL will be highly alkaline $(\sim 12.3)$ after the hematite reduction, which explains the

$4 \mathrm{Fe}^{3+/ 2+}$ system shape. We also made the same kind of calculations for the voltammogram obtained with the CPEEB [22]. Given that $1.6 \mathrm{mg}$ of $\mathrm{Fe}_{2} \mathrm{O}_{3}\left(10^{-5} \mathrm{~mol}\right)$ and $50 \mu \mathrm{L}$ of $10^{-2} \mathrm{M}$

$6 \mathrm{HCl}\left(5 \times 10^{-7} \mathrm{~mol}\right)$ were used for the preparation of the carbon paste there is a serious shortage of protons for the complete reduction of hematite. We estimated that approximately $7 \times 10^{-7}$ 8 mol of $\mathrm{Fe}_{2} \mathrm{O}_{3}$ were reduced at peak $\mathrm{C}^{\circ}$, by integration of the voltammetric curve, which correspond to a $0.14 \mathrm{C}$ charge. It is unclear in ref. [22] if the electrode was filled with the 10 whole of the carbon paste or not. We accepted the most favourable hypothesis i.e. the totality of the carbon past was used and therefore $5 \times 10^{-7} \mathrm{~mol}$ of $\mathrm{H}^{+}$are present inside the electrode, whereas only $7 \%$ of the initial hematite was electrochemically reduced. As the reduction of $7 \times 10^{-7}$ mol of $\mathrm{Fe}_{2} \mathrm{O}_{3}$ requires $4.2 \times 10^{-6}$ mol of $\mathrm{H}^{+}$, the $\mathrm{H}^{+} / \mathrm{Fe}_{2} \mathrm{O}_{3}$ ratio is much more unfavourable than in the case of VMPTL and the shape of the voltammogram in Figure 8B is totally incompatible with such a high $\mathrm{pH}$ value unless there is a massive introduction of $\mathrm{H}^{+}$ from the solution into the paste.

Figure 6C illustrates an attempt to prevent the $\mathrm{Fe}(\mathrm{III})$ precipitation in the $10 \mathrm{mM} \mathrm{HCl}$ medium by formation of the anionic complex $\mathrm{FeCl}_{4}{ }^{-}$after the addition of a massive amount of chloride ion. This is why the series of voltammograms in Figure $6 \mathrm{C}$ was recorded in the $10 \mathrm{mM} \mathrm{HCl}+$ $1 \mathrm{M} \mathrm{KCl}$ mixture by decreasing dramatically the amount of $\mathrm{Fe}_{2} \mathrm{O}_{3}$ immobilized in the TL. In the forward scan, the signal $\mathrm{C}^{\circ}$ for the $\mathrm{Fe}_{2} \mathrm{O}_{3}$ reduction is no more a sharp peak, as in Figure $6 \mathrm{~B}$, but a wide signal that is composed of two successive steps at -0.20 and $-0.37 \mathrm{~V}$ as in Figure 6A. After the reversal of the scan direction, a well defined anodic peak A1 is observed at $0.48 \mathrm{~V}$ for the $\mathrm{Fe}(\mathrm{II})$ oxidation, then, following a second scan reversal, peak $\mathrm{C} 1$ for the $\mathrm{Fe}(\mathrm{III})$ reduction appears at $0.42 \mathrm{~V}$. However, the C1/A1 height ratio is only 0.69 . During the 
next cycles, the cathodic signal $\mathrm{C}^{\circ}$ remains virtually unchanged whereas peaks $\mathrm{A} 1$ and $\mathrm{C} 1$

2 progressively grow towards constant heights with an $\mathrm{A} 1 / \mathrm{C} 1$ ratio about 0.77 . What is notable is that it is as hematite was regenerated at every voltammetric cycle. Probably, the mechanism is complex and may involve the formation of green rusts [33]; therefore, specific investigation is required that is beyond the scope of this article.

6 3.3. Characterization of electroactive compounds present at percent levels in different matrices

8 After showing the interest of VMPTL for the characterization of pure solids, it is extended here in species that are present at very low amounts in more or less complex matrices, i.e. a 10 palladium-based catalyst and a pyrite containing natural rock.

\subsubsection{Palladium supported on alumina catalyst (Pd/Al/Cat)}

12 The hydrogenation aromatic rings, the oxidation of methane [34] and glucose [35], the deoxygenation of inert gases [36], the fuel cells [37,38] and the combustion in gas turbines [39] are among the numerous applications of $\mathrm{Pd} / \mathrm{Al} / \mathrm{Cats}$. In the environmental area, $\mathrm{Pd} / \mathrm{Al} / \mathrm{Cats}$ are used for the reductive dehalogenation of chlorinated hydrocarbons or the hydrogenation of aromatic compounds in groundwater [40,41] and the exhaust emissions $\left(\mathrm{NO}_{\mathrm{x}}+\mathrm{CO}\right)$ transformation in the automotive [42,43]. Vibrational spectroscopy has been mainly used for the $\mathrm{Pd} / \mathrm{Al} / \mathrm{Cats}$ characterization [44-47]; it showed that an oxidation phenomenon occurred on the $\mathrm{Pd}$ surface with formation of $\mathrm{PdO}$ when the catalysts were in contact with air, even at room temperature. Their regeneration requires the reduction of the oxide by gaseous hydrogen at high temperatures. Finally, the Bauer group investigated in 1992 the electrochemical characterization of palladium compounds, including palladium automotive catalysts, by means of CPEEBs $[48,49]$.

The experiments were performed in $1 \mathrm{M} \mathrm{KCl}$ at $\mathrm{pH} 2$, in order to lower the $\mathrm{Pd}^{\circ}$ oxidation potential by the formation of palladium chloro-complexes and avoid the production of 
palladium monoxide which is insoluble in all acids, including aqua regia [50,51]. The

2 speciation diagram that we plotted for $50 \mathrm{mM} \mathrm{Pd}(\mathrm{II})$ in $1 \mathrm{M} \mathrm{KCl}$ shows that if $\mathrm{pH}<2.25$ the whole quantity of $\mathrm{Pd}(\mathrm{II})$ is under the anionic forms $\mathrm{PdCl}_{4}{ }^{2-}(95 \%)$ and $\mathrm{PdCl}_{3}{ }^{-}(5 \%)$.

The VMPTL voltammograms recorded at $5 \mathrm{mV} / \mathrm{s}$ for Pd/Al/Cat microparticles obtained after grinding of the commercial pellets are displayed in Figures 9A and 9B.

6 In Figure 9A, the potential sweep was started from the OCP in the positive direction. At the first voltammetric cycle the anodic peak $\mathrm{A} 1^{\circ}(0.64 \mathrm{~V})$ corresponds to the oxidation of the alumina-supported metallic $\mathrm{Pd}$ particles in $\mathrm{PdCl}_{4}{ }^{2-}$. After the potential reversal, the cathodic peak $\mathrm{C}^{\circ}(0.00 \mathrm{~V})$ is ascribed to the deposition on the graphite surface of $\mathrm{Pd}^{\circ}$ that results from the reduction of: (i) $\mathrm{PdCl}_{4}{ }^{2-}$, released at $\mathrm{A}^{\circ}$ and (ii) $\mathrm{PdO}$ originally present on the catalyst surface (see Fig. 9B). Indeed, the peak $\mathrm{C}^{\circ}$ area is much greater than that of $\mathrm{A} 1^{\circ}$ $\left(\mathrm{C} 1^{\circ} / \mathrm{A} 1^{\circ} \approx 1.7\right)$. At the second cycle, the stripping of $\mathrm{Pd}^{\circ}$ deposited on the graphite surface during $\mathrm{C}^{\circ}$ occurs at lower potentials (peak $\mathrm{A} 1$ at $0.58 \mathrm{~V}$ ) than that originally present on $\mathrm{Al}_{2} \mathrm{O}_{3}$. However, the $\mathrm{A} 1 / \mathrm{C}^{\circ}{ }^{\circ}$ area ratio is about 0.6 ; that means that either a large part of the $\mathrm{Pd}^{\circ}$ formed at $\mathrm{C}^{\circ}$ is no more in electric contact with the graphite or the air-oxidized palladium on the $\mathrm{Pd} / \mathrm{Al} / \mathrm{Cat}$ surface was at an oxidation state higher than 2 . After the scan direction reversal, $\mathrm{PdCl}_{4}{ }^{2-}$ is reduced at peak $\mathrm{C} 1(0.02 \mathrm{~V})$, which is thinner than $\mathrm{C}^{\circ}$ because of the absence of $\mathrm{PdO}$, and $\mathrm{C} 1 / \mathrm{A} 1 \approx 1.2$. At the third and forth cycles, the $\mathrm{C} 1 / \mathrm{A} 1$ area ratio tends towards 1 and the voltammetric peaks height progressively decreases. This is probably the result of the gradual adsorption of $\mathrm{PdCl}_{4}{ }^{2-}$ on alumina, which, according to electrokinetic measurements [52], is positively charged for $\mathrm{pH}$ values smaller than 8-9 whatever the origin and the crystalline structure of $\mathrm{Al}_{2} \mathrm{O}_{3}$. The positions of peaks $\mathrm{C} 1(0.02 \mathrm{~V})$, for the $\mathrm{PdCl}_{4}{ }^{2-}$ reduction, and $\mathrm{A} 1(0.58 \mathrm{~V})$ for the $\mathrm{Pd}^{\circ}$ stripping on graphite have been confirmed by the voltammogram recorded for $1 \mathrm{mM} \mathrm{PdCl}_{2}$ in the same medium (Fig. 9C curve c). Therefore, the kinetics of the $\mathrm{PdCl}_{4}{ }^{2-} / \mathrm{Pd}$ system is slow. In the literature the positions of peaks $\mathrm{A} 1$ and 
$\mathrm{C} 1$ are very dependent on the experimental conditions: 0.66 and $0.00 \mathrm{~V}$ vs. SCE, respectively,

2 at a carbon felt in $0.1 \mathrm{M} \mathrm{HCl}$ [53], 0.36 and $0.174 \mathrm{~V}$ vs. SCE at a CPEEB in $2 \mathrm{M} \mathrm{HCl} \mathrm{[48],}$ 0.67 and $0.26 \mathrm{~V}$ vs. SCE at a vitreous carbon electrode in $0.03 \mathrm{M} \mathrm{HCl}+0.8 \mathrm{M} \mathrm{HClO}_{4}$ [54]. As regards the $\mathrm{PdCl}_{4}{ }^{2-} / \mathrm{Pd}$ standard potential, there are some inconsistencies in the literature where $\mathrm{E}^{\circ}$ varies from 0.580 to $0.646 \mathrm{~V}$ vs. SHE [55-61]. The PdO reduction potential, which

6 depends on the $\mathrm{pH}$, was observed at $-0.165 \mathrm{vs}$. $\mathrm{Ag} / \mathrm{QREF}$ at $\mathrm{pH} 2$ in the present study, -0.100 vs SCE at a CPEEB in $2 \mathrm{M} \mathrm{HCl}$ [48], $0.529 \mathrm{~V}$ vs. the reversible hydrogen electrode (RHE) at a Pd electrode in $0.5 \mathrm{M} \mathrm{H}_{2} \mathrm{SO}_{4}$ [62] and 0.76 vs. RHE at a smooth Pd electrode in $1 \mathrm{M} \mathrm{H}_{2} \mathrm{SO}_{4}$ [63]. The $\mathrm{E}^{\circ} \mathrm{PdO} / \mathrm{Pd}$ standard potential, ranges between 0.87 and $0.91 \mathrm{~V}$ vs. SHE $10[51,55,62,64,65]$. Therefore, the normal apparent potential at $\mathrm{pH} 2$ is about $0.80 \mathrm{~V}$ vs. SHE ( 0.57 V vs. Ag/QREF).

When the voltammograms are recorded in the negative direction (Fig. 9B), at the first cycle, the broad signal $\mathrm{C} 0$ going from 0.1 to $-0.2 \mathrm{~V}$ corresponds to the $\mathrm{PdO}$ reduction in $\mathrm{Pd}^{\circ}$. After reversal of the scan direction, two anodic stripping signals appear: (i) A0 for the elemental palladium deposited onto graphite surface during the $\mathrm{PdO}$ reduction and (ii) $\mathrm{A} 1^{\circ}$ to the $\mathrm{Pd}$ originally present on $\mathrm{Al}_{2} \mathrm{O}_{3}$. The $\left(\mathrm{A} 0+\mathrm{A} 1^{\circ}\right) / \mathrm{C} 0$ peaks area ratio is about 3 . Then, after the scan reversal $\left(\mathrm{A} 0+\mathrm{A} 1^{\circ}\right) / \mathrm{C} 1=1.3$. At the second and third cycles, as for the voltammograms recorded in the positive direction, the heights of peaks $\mathrm{A} 1$ and $\mathrm{C} 1$ progressively decreases and their ratio tends to 1 .

The voltammogram obtained with an automotive Pd catalyst using a CPEEB at a $0.25 \mathrm{mV} / \mathrm{s}$ scan rate in $2 \mathrm{M} \mathrm{HCl}$ (digitized from reference [48]) is represented in Figure 9C (curves a and b). The comparison with the VMPTL voltammograms shows that, even if the potentials of peaks $\mathrm{A} 0, \mathrm{~A} 1, \mathrm{C} 0$ and $\mathrm{C} 1$ are different because of the high acidic level used with the CPEEB the interpretation is the same. Thus, the results are qualitatively similar and those for VMPTL can be obtained 20 times faster. 


\subsubsection{Pyrite containing Callovo-Oxfordian argillite (COx) from Bure}

2 In several studies on the underground landfill of spent nuclear fuel, it is accepted that small amounts of pyrite $(\sim 1 \mathrm{wt} . \%)$ will be responsible for the low redox potential of argillaceous soils envisaged for the fuel storage [66]. Therefore, it is important to examine if electrochemical techniques could be a useful tool to investigate the reactivity of minerals

6 included in these subsoils. Bure is the French site planned for the deep repository of high activity long life radioactive waste [67]. The experiments have been performed in chloride medium $(10 \mathrm{mM} \mathrm{HCl}+1 \mathrm{M} \mathrm{KCl})$, because the chloride concentration in the Bure clay poral water ranges from 0.01 to $0.5 \mathrm{M}$ according to the localization of the analysed samples [68].

The voltammogram for COx grains entrapped in the VPMTL device is shown in Figure 10. The potential scan was started from the OCP $(0.07 \mathrm{~V} v s . \mathrm{Ag} / \mathrm{QREF})$ in the positive direction. The anodic peak A1 that appears at about $0.99 \mathrm{~V}$, just before the anodic limit, is due to the pyrite oxidation. During the reverse scan, we can see the reduction of species issued from the $\mathrm{FeS}_{2}$ oxidation: $\mathrm{Fe}(\mathrm{III})$ at peak $\mathrm{C} 2(0.40 \mathrm{~V})$, and a mixture of $\mathrm{S}_{8}, \mathrm{~S}_{\mathrm{x}}{ }^{2-}$ and oxysulphur compounds $\left(\mathrm{S}_{2} \mathrm{O}_{3}{ }^{2-}, \mathrm{S}_{4} \mathrm{O}_{6}{ }^{2-} \ldots\right)$ [69-71] at peak $\mathrm{C} 3(-0.50 \mathrm{~V})$. In the second cycle, one can remark the appearance of peak $\mathrm{A} 2(\sim 0.59 \mathrm{~V})$ for the oxidation of $\mathrm{Fe}^{2+}$ ions formed at $\mathrm{C} 2$ and the dramatic decrease of peak A1. Therefore, almost the whole of pyrite comprised in the clay has been oxidized during the first cycle. Peak C2 is superimposable to that of the first cycle. It is difficult to have an exact estimation of the $\mathrm{A} 1 / \mathrm{C} 2$ peak area ratio because $\mathrm{A} 1$ and the oxidation of chloride ions are too close. However, the very approximate experimental value of 16 that we determined is in favour of the formation of oxysulphur compounds like $\mathrm{SO}_{4}{ }^{2-}$, $\mathrm{S}_{2} \mathrm{O}_{3}{ }^{2-}, \mathrm{S}_{4} \mathrm{O}_{6}{ }^{2-}$...during the oxidation of pyrite. For example, the reaction $\mathrm{FeS}_{2}+8 \mathrm{H}_{2} \mathrm{O}+\mathrm{Cl}^{-}$ $\rightarrow \mathrm{FeCl}^{2+}+2 \mathrm{SO}_{4}^{2-}+16 \mathrm{H}^{+}+15 \mathrm{e}^{-}$would lead to an $\mathrm{A} 1 / \mathrm{C} 2$ peak area ratio of 15 . Because of the fundamental importance of the electrochemical characterization of $\mathrm{COx}$, a more detailed presentation will be the subject of a separate paper. 


\section{References}

\section{Conclusions} (2013) 609.

We hope that this article could convince the reader of the usefulness of VMPTL that enables to characterize electrochemically not only pure solids but also compounds that are in very low amounts in complex matrixes. As this technique provides information on the soluble species formed at the surface of the immobilized electroactive microparticles, it is an efficient tool, complementary to VMP. Moreover, VMPTL, from just a few $\mu \mathrm{g}$ of matter, gives equivalent results as CPEEBs using scan rates more than ten times faster with better resolution and higher signal-to-noise ratio, especially if the experiments are made in low conducting media. The voltammograms recorded in this study with ferrocene, pyrolusite and an aluminasupported palladium catalyst are in good agreement with the literature ones obtained using CPEEBs, while those for hematite lead us to suspect a complex mechanism. Finally, VPMTL has been successfully applied to a sample of Callovo-Oxfordian argillite.

\section{Acknowledgements}

The authors would like to acknowledge Mr. J.P. Moulin for his contribution in the development of the VMPTL device and Prof. Cathelineau for providing the argillite sample.

[1] F. Scholz, B. Meyer, Voltammetry of solid microparticles immobilized on electrode surfaces, in: A. J. Bard, I. Rubinstein (Eds.), Electroanalytical Chemistry, A Series of Advances (Edts.), Vol. 20, Marcel Dekker, 1998, p. 1-86.

[2] F. Scholz, U. Schröder, R. Gulaboski, A. Doménech-Carbó, Electrochemistry of Immobilized Particles and Droplets, Springer, Berlin 2015.

[3] A. Doménech-Carbó, J. Labuda, F. Scholz, Electroanalytical chemistry for the analysis of solids: Characterization and classification (IUPAC Technical Report), Pure Appl. Chem., 85,

28 [3] A. Doménech, M.T. Doménech-Carbó, H.G. M. Edwards, Identification of Earth Pigments by Applying Hierarchical Cluster Analysis to Solid State Voltammetry. Application to Severely Damaged Frescoes, Electroanalysis, 19 (2007) 1890.

[5] A Doménech-Carbó, M.T. Doménech-Carbó, M. Calistia, V. Maiolo, Sequential 
identification of organic dyes using the voltammetry of microparticles approach, Talanta, 81 , 2 (2010) 404.

[6] D. Bauer, M.Ph. Gaillochet, Etude du comportement de la pâte de carbone à compose électroactif incorporé, Electrochim. Acta, 19 (1974) 597.

[7] M. Lamache, D. Bauer, Étude, par chronoampérométrie, de l'électrode à pâte de carbone à

liant électrolytique et solide électroactif incorporé, J. Electroanal. Chem., 79 (1977) 359.

[8] M. Lamache, Electrode à pate de carbone à liant électrolytique et composes électroactifs

peu solubles incorpores: aspects quantitatifs, Electrochim. Acta., 24 (1979) 79.

[9] K. Kalcher, Chemically modified carbon paste electrodes in voltammetric analysis, Electroanalysis, 2 (1990) 419.

[10] P. Gaillochet, D. Bauer, M.C. Hennion, Dosage rapide de l'uranium dans ses minerais à l'aide de l'électrode de pâte de carbone, Analusis, 3 (1975) 513.

[11] M. Lamache, D. Kendé, D. Bauer, Etude du comportement électrochimique de sulfures naturels peu solubles : chalcocite, covellite, chalcopyrite, Analusis, 1 (1977) 377.

[12] M.C. Brage, M. Lamache, D. Bauer, Dosage de sulfures de cuivre à l'aide de l'électrode à pâte de carbone, Analusis, 6 (1978) 284.

[13] M.C. Brage, M. Lamache, D. Bauer, Contribution à l'étude des sulfures de cuivre non stœchiométriques, Electrochim. Acta, 24 (1979) 25.

[14] M. Lamache, D. Bauer, Anodic oxidation of cuprous sulfide and the preparation of nonstoichiometric copper sulphide, Anal. Chem., 51 (1979) 1320.

[15] A. Andriamanana, M. Lamache, D. Bauer, Etude électrochimique de différentes ilménites, Electrochim. Acta, 29 (1984) 1051.

[16] M. T. Mouhandess, F. Chassagneux, et O. Vittori, Influence de la morphologie de l'oxyde de fer, $\alpha \mathrm{Fe}_{2} \mathrm{O}_{3}$, sur son comportement électrochimique, C. R. Acad. Sc. Paris, 290 (1980) 267.

[17] P. Encinas, L. Lorenzo, M.L. Tascón, M.D. Vázquez, P. Sánchez-Batanero, Electrochemical study of iron(II) and iron(III) compound mixtures in the solid state. Application to magnetite characterization, J. Electroanal. Chem. 371 (1994) 161.

[18] J.M. Lecuire, Comportement électrochimique de différents oxydes de fer. I. Etude voltampérométrique de la réduction en milieu acide de poudres cristallisées incluses dans une pâte de graphite, Analusis, 2 (1973) 489.

[19] J.M. Lecuire, Comportement électrochimique de différents oxydes de fer. II. Etude des espèces passant en solution par la méthode du disque et de l'anneau, Analusis, 2 (1973) 495.

[20] J.M. Lecuire, Réduction électrochimique des oxydes de fer: Application à la mesure de non stoechiométrie, J. Electroanal. Chem. 66 (1975) 195.

[21] P. Encinas Bachiller, M.L. Tascón Garcia, M.D. Vázquez Barbado, P. Sánchez-Batanero, Electroanalytical study of copper and iron compounds in the solid state: application to copper ferrite characterization, J. Electroanal. Chem. 367 (1994) 99.

[22] L. Lorenzo, P. Encinas, M. L. Tascón, M. D. Vázquez, C. de Francisco, P. SánchezBatanero, Electrochemical study of manganese and iron compounds at carbon paste electrodes with electrolytic binder. Application to the characterization of manganese ferrite, J. Solid State Electrochem., 1 (1997) 232.

[23] M.T. Ramírez, M.E. Palomar, I. González, A. Rojas-Hernández, Carbon paste electrodes with electrolytic binder: Influence of the preparation method, Electroanalysis, 7 (1995) 184.

[24] M.T. Mouhandess, F. Chassagneux, O. Vittori, Electrochemical behaviour of $\alpha-\mathrm{Fe}_{2} \mathrm{O}_{3}$ using carbon paste electrodes: Influence of particle size, J. Electroanal. Chem. 131 (1982) 367.

[25] M.T. Mouhandess, F. Chassagneux, O. Vittori, A. Accary, Some theoretical aspects of electrodissolution of iron oxide $\left(\alpha-\mathrm{Fe}_{2} \mathrm{O}_{3}\right)$ in carbon paste electrodes with acidic binder, J. Electroanal. Chem. 181 (1984) 93. 
[26] C.N. Reilley, Electrochemistry Using Thin-Layer Cells, Rev. Pure and Appl. Chem., 18 (1968) 137.

[27] M. Perdicakis, Q. Qin, M. Bertucci, H. Aubriet, Voltammetry of MicroParticles in Thin Layer (VMPTL), presentation at the $11^{\text {th }}$ International Conference on Electroanalysis, Bordeaux, France, June 11-15th 2006.

[28] A. Doménech-Carbó, I. Domínguez, P. Hernández-Muñoz, R. Gavara, Electrochemical tomato (Solanum lycopersicum L.) characterisation using contact probe in situ voltammetry, Food Chem. 172 (2015) 318.

[29] A. Doménech-Carbó, A.M. Ibars, J. Prieto-Mossi, E. Estrelles, F. Scholz, G. CebriánTorrejóna, M. Martinia, Electrochemistry-based chemotaxonomy in plants using the voltammetry of microparticles methodology, New J. Chem., 39 (2015) 7421.

[30] E. Gaucher, C. Robelin, J.M. Matray, G. Négrel, Y. Gros, J.F. Heitz, A. Vinsot, H. Rebours, A. Cassagnabère, A. Bouchet, ANDRA underground research laboratory: interpretation of the mineralogical and geochemical data acquired in the Callovian-Oxfordian formation by investigative drilling, Phys. Chem. Earth, 29 (2004) 55.

[31] B. Trémillon, Electrochimie analytique et réactions en solution, vol 2, Masson S.A. ed., Paris 1993.

[32] A. Azra Bilgin, J. Silverstein, M. Hernandez, Effects of Soluble Ferri-Hydroxide Complexes on Microbial Neutralization of Acid Mine Drainage, Environ. Sci. Technol., 39 (20) 7826.

[33] J.M.R. Génin, Ph. Refait, L. Simon, S.H. Drissi, Preparation and Eh-pH diagrams of $\mathrm{Fe}(\mathrm{II})-\mathrm{Fe}(\mathrm{III})$ green rust compounds; hyperfine interaction characteristics and stoichiometry of hydroxy-chloride, -sulphate and -carbonate, Hyp. Interact., 111 (1998) 313.

[34] D.O. Simone, T. Kennelly, N.L. Brungard, R.J. Farrauto, Reversible poisoning of palladium catalysts for methane oxidation, Appl. Catal., 70 (1991) 87.

[35] I. Nikov, K. Paev, Palladium on alumina catalyst for glucose oxidation: reaction kinetics and catalyst deactivation, Catal. Today, 24 (1995) 41.

[36] B. Nowicki, A. Masiarz, D. Maksymiec, M. Zawadzki, D. Gniady, S. Zawadzka, W. Jaglarz, Method for preparing catalysts for oxygen removal from neutral gases, Patent PL281433 (A1) - 1991-03-25.

[37] Y.H. Wang, J.C. Zhang, Hydrogen production on $\mathrm{Ni}-\mathrm{Pd}-\mathrm{Ce} / \gamma-\mathrm{Al}_{2} \mathrm{O}_{3}$ catalyst by partial oxidation and steam reforming of hydrocarbons for potential application in fuel cells, Fuel, 84 (2005) 1926.

[38] E.J. Weston, R.S. Spivey, W.M. Faris, Combination of zeolite and alumina impregnated with noble metal(s) for carbonyl sulfide and the removal at low temperatures in fuel cell processor applications, U.S. Pat. Appl. Publ. (2007), US 20070119751 A1 20070531.

[39] S.R. Vatcha, Low-emission gas turbines using catalytic combustion, Energ. Convers. Manage., 38, (1997) 1327.

[40] A. David, M.A. Vannice, Control of catalytic debenzylation and dehalogenation reactions during liquid-phase reduction by $\mathrm{H}_{2}$, J. Catal., 237 (2006) 349.

[41] D.P. Siantar, C.G. Schreier, C.S. Chou, M. Reinhard, Treatment of 1,2-dibromo-3chloropropane and nitrate-contaminated water with zero-valent iron or hydrogen/palladium catalysts, Water Res., 30 (1996) 2315.

[42] J.R. Gonzalez-Velasco, M.A. Gutierrez-Ortiz, J.A. Botas, S. Bernal, J.M. Gatica, J.A. Perez-Omil, HREM and XRD characterization of thermal ageing of $\mathrm{Pd} / \mathrm{CeO}_{2} / \mathrm{Al}_{2} \mathrm{O}_{3}$ automotive catalysts, Stud. Surf. Sci. Catal., 126 (1999) 187.

[43] Hideaki Muraki, Koji Yokota, Yoshiyasu Fujitani, Nitric oxide reduction performance of automotive palladium catalysts, Appl. Catal., 48 (1989) 93.

[44] A.S. Mamede, G. Leclercq, E. Payen, P. Granger, J. Grimblot, In situ Raman characterisation of surface modifications during NO transformation over automotive Pd-based 
exhaust catalysts, J. Mol. Struct., 651-653, (2003) 353.

2 [45] A.S. Mamede, G. Leclercq, E. Payen, J. Grimblot, P. Granger, Surface Raman spectroscopic study of NO transformation over Pd-based catalysts, Phys. Chem. Chem. Phys.,

$4 \quad 5$ (2003) 4402.

[46] G. Le Bourdon, F. Adar, M. Moreau, S. Morel, J. Reffner, A.S. Mamede, C. Dujardin, E.

6 Payen, In situ characterization by Raman and IR vibrational spectroscopies on a single instrument: DeNOx reaction over a $\mathrm{Pd} / \gamma-\mathrm{Al}_{2} \mathrm{O}_{3}$ catalyst, Phys. Chem. Chem. Phys., 5 (2003) 4441.

[47] In Situ Characterisation of Heterogeneous Catalytic Reactions by Raman and IR Vibrational Spectroscopies on a single Instrument, Horiba Jobin Yvon, Raman Application Note, http://www.horiba.com/fileadmin/uploads/Scientific/Documents/Raman/Solidstate02.pdf (Downloaded on October 16, 2015). [48] F.A. Adekola, M. Diaw, C. Colin, D. Bauer, Electrochemical study of some palladium compounds at a carbon paste electrode - application to the determination of palladium in oxidation automotive catalysts, Electrochim. Acta, 37 (1992) 2491.

[49] F.A. Adekola, C. Colin, D. Bauer, Electrochemical behaviour of some automotive catalysts at a carbon paste electrode and with electrolytic binder, Electrochim. Acta, 37 (1992) 2009.

[50] H. Remy, Treatise on Inorganic Chemistry, (Ed. J. Kleinberg), Elsevier Publishing Company, Amsterdam 1970, Volume II p.340.

[51] C. Duval, in Nouveau Traité de Chimie Minérale, (Ed. P. Pascal), Masson et Cie, Paris 1958, Volume XIX p.610.

[52] M. Kosmulski, pH-dependent surface charging and points of zero charge II. Update, J. Colloid Interface Sci., 275 (2004) 214.

[53] A.M. Polcaro, M.S. Dernini, S. Palmas, Electrodeposition of catalysts for hydrogenation of organic molecules: hydrogenation of benzaldehyde, Electrochim. Acta, 37 (1992) 365. $15-25$ Physicalchemical properties of acido complexes of palladium(II) in aqueous dioxane media, Zh. Neorg. Khim. 13 (1968) 3306.

[56] A.B. Fasman, G.G. Kutuykov, D.V. Sokol'skii, Reactivity of complex compounds of palladium(II) in aqueous solutions, Zh. Neorg. Khim., 10 (1965) 1338.

[57] P. Vanýsek in CRC Handbook of Chemistry and Physics, $96^{\text {th }}$ edition, W. M. Haynes, Taylor \& Francis Group, Boca Raton 2015.

[58] N.M. Nikolaeva, L.D. Tsvelodub, A.M.Erenburg, Effect of temperature on standard potentials of palladium(II) halo complexes, Izv. Sib. Otd. An. Khim+., (1978) 44.

[59] N.A. Polotnyanko, I.L. Khodakovskii, Thermodynamic properties of Pd chloride complexes and the $\mathrm{Pd}^{2+}(\mathrm{aq})$ ion in aqueous solutions, Geochem. Int., 52 (2014) 46.

[60] D.H. Templeton, G.W. Watt, C.S. Garner, The Formal Electrode Potentials of Palladium in Aqueous Hydrochloric and Perchloric Acid Solutions. Stability of Chloropalladite Ion, J. Am. Chem. Soc., 65 (1943) 1608.

[61] B.R. Tagirov, N.N. Baranova, A.V. Zotov, N.N. Akinfiev, N.A. Polotnyanko, N.D. Shikina, L.A. Koroleva, Y.V. Shvarov, E.N. Bastrakov, The speciation and transport of palladium in hydrothermal fluids: Experimental modeling and thermodynamic constraints, Geochim. Cosmochim. Acta, 117 (2013) 348.

[62] L.H. Dall'Antonia, G. Tremiliosi-Filho, G. Jerkiewicza, Influence of temperature on the growth of surface oxides on palladium electrodes, J. Electroanal. Chem., 502 (2001) 72. 
multilayer oxide films on palladium in aqueous media, J. Electroanal Chem., 186 (1985) 139.

2 [64] Techniques de l'ingénieur, Archives, Enthalpie et Enthalpie libre de Formation, Volume K610 (Ed. C. Montel Paris 1955).

4 [65] M.J.N. Pourbaix, J. Van Muylder and N. de Zoubov, Electrochemical Properties of the Platinum Metals, Platinum Metals Rev., 3 (1959) 100.

6 [66] F.J. Pearson, D. Arcos, A. Bath, J.Y. Boisson, A.M. Fernández, H.E. Gäbler, E. Gaucher, A. Gautschi, L. Griffault, P. Hernán, H.N. Waber, Mont Terri Project - Geochemistry of Water in the Opalinus Clay Formation at the Mont Terri Rock Laboratory, Reports of the Federal Office for Water and Geology, Geology Series, N5, Bern 2003.

10 [67] French National Radioactive Waste Management Agency (ANDRA). The Meuse/HauteMarne Underground Research Laboratory (MHM URL): a scientific tool. http://www.andra.fr/download/andra-international-en/document/editions/182.pdf (Downloaded on September 2, 2015).

14 [68] French National Radioactive Waste Management Agency (ANDRA), Report DNT-AHYG97.002, 1997.

16 [69] G.H. Kelsall, Q. Yin, D.J. Vaughan, K.E.R. England, N.P. Brandon, Electrochemical oxidation of pyrite $\left(\mathrm{FeS}_{2}\right)$ in aqueous electrolytes, J. Electroanal. Chem., 471 (1999) 116.

[70] M.M. Antonijević, M.D. Dimitrijević, S.M. Šerbula, V.L.J. Dimitrijević, G.D. Bogdanović, S.M. Milić, Influence of inorganic anions on electrochemical behaviour of pyrite, Electrochim. Acta, 50 (2005) 4160.

[71] M. Descostes, P. Vitorge, C. Beaucaire, Pyrite dissolution in acidic media, Geochim. Cosmochim. Acta, 68, (2004) 4559. 


\section{Figure Captions}

2 Fig. 1. The VMPTL electrochemical cell: (A) experimental setup, (B) schematic representation of the cell design.

4 Fig. 2. Electroactive solids present at percent levels in different matrices: (A) Aluminasupported palladium catalyst (scanning electron photomicrograph, back-scattered electron

6 image), (B) Pyrite-containing Callovo-Oxfordian argillite (optical microscopy photograph).

Fig. 3. Voltammetric behaviour of $2 \mathrm{mM} \mathrm{K}_{4} \mathrm{Fe}(\mathrm{CN})_{6}$ in $1 \mathrm{M} \mathrm{KCl}$ using the VMPTL device.

8 (A) Cyclic voltammograms for different scan rates. (B and C) Analysis of the variation of the voltammograms characteristics with the scan rate: Separation between the anodic and cathodic peak (B), Anodic peak current (C).

Fig. 4. Voltammetric characterization of ferrocene microparticles in $1.4 \mathrm{M} \mathrm{H}_{2} \mathrm{SO}_{4}$ using VMPTL: (A) Two first cycles and comparison with CPEEB (reproduced with permission from [6]), (B). Stabilized voltammograms for different scan rates.

Fig. 5. Voltammetric characterization of $\mathrm{MnO}_{2}$ microparticles in $10 \mathrm{mM} \mathrm{HCl}$ using VMPTL and a CPEEB (reproduced with permission from ref. [22]). Scans started from the OCP in the negative direction.

Fig. 6. Voltammetric characterization of $\mathrm{Fe}_{2} \mathrm{O}_{3}$ microparticles: (A) Curve (a) $1 \mathrm{M} \mathrm{KCl}$, pH 1 VMPTL at $5 \mathrm{mV} / \mathrm{s}$; Curve (b) $1 \mathrm{M} \mathrm{HCl} \mathrm{CPEEB,} \mathrm{at} 0.5 \mathrm{mV} / \mathrm{s}$ (reproduced with permission from ref. [21], (B) $10 \mathrm{mM} \mathrm{HCl,} \mathrm{VMPTL} \mathrm{(curve} \mathrm{a),} \mathrm{CPEEB} \mathrm{(curve} \mathrm{b} \mathrm{reproduced} \mathrm{with}$ permission from ref. [22]). 
Fig. 7. Voltammetric characterization of palladium supported on alumina catalyst (all scans

2 started from the OCP): (A) VMPTL in $1 \mathrm{M} \mathrm{KCl}$ at $\mathrm{pH} 2$, in the positive direction $(v=5 \mathrm{mV} / \mathrm{s})$, (B) VMPTL in $1 \mathrm{M} \mathrm{KCl}$ at $\mathrm{pH} 2$, in the negative direction $(v=5 \mathrm{mV} / \mathrm{s})$,

4 (C): curves a and b CPEEB in $2 \mathrm{M} \mathrm{HCl}$ in the negative direction (reproduced with permission from ref. [48], $v=0.25 \mathrm{mV} / \mathrm{s}$ ) and curve c, electrochemical behaviour of $1 \mathrm{mM} \mathrm{PdCl}_{2}$ thin 6 layer in $1 \mathrm{M} \mathrm{KCl}$ at $\mathrm{pH} 2(v=5 \mathrm{mV} / \mathrm{s})$.

Fig. 8. Voltammetric characterization of Callovo-Oxfordian argillite in $1 \mathrm{M} \mathrm{KCl} \mathrm{pH} 2$ using

8 VMPTL. Scan started from the OCP in the positive direction, $v=5 \mathrm{mV} / \mathrm{s}$. 


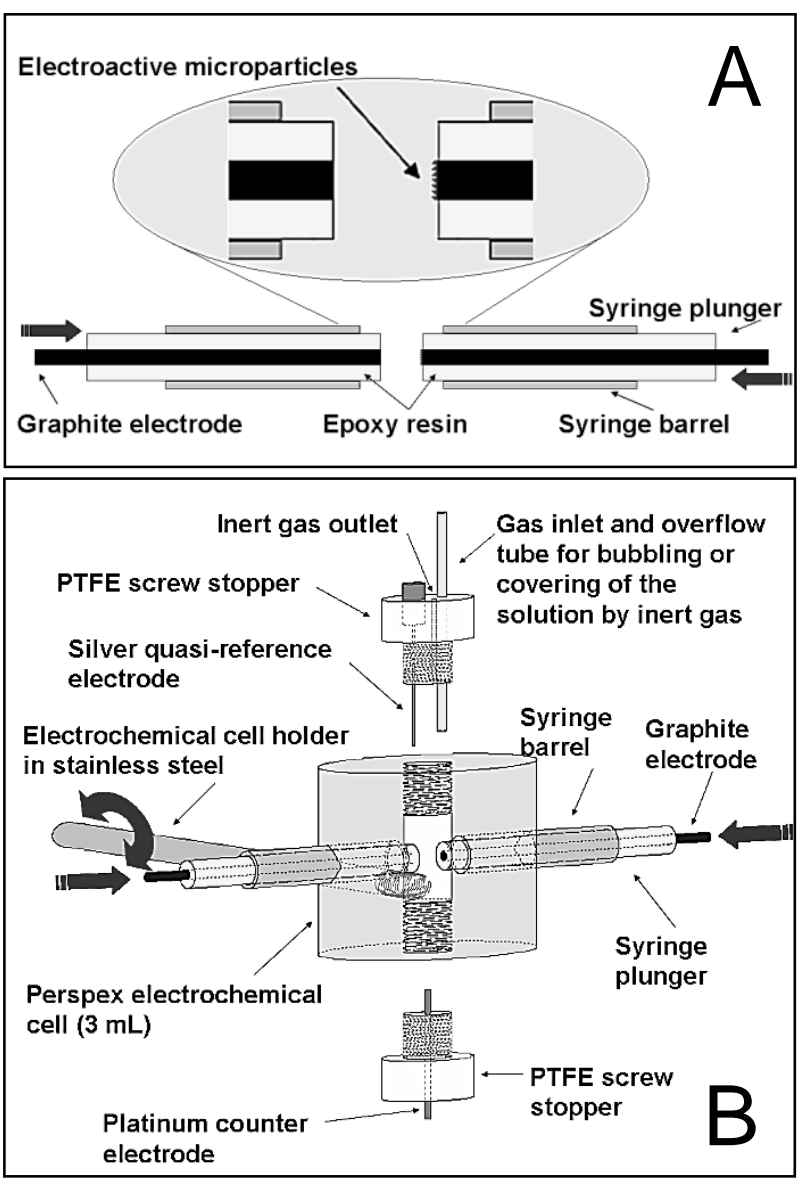

Fig. 1

2
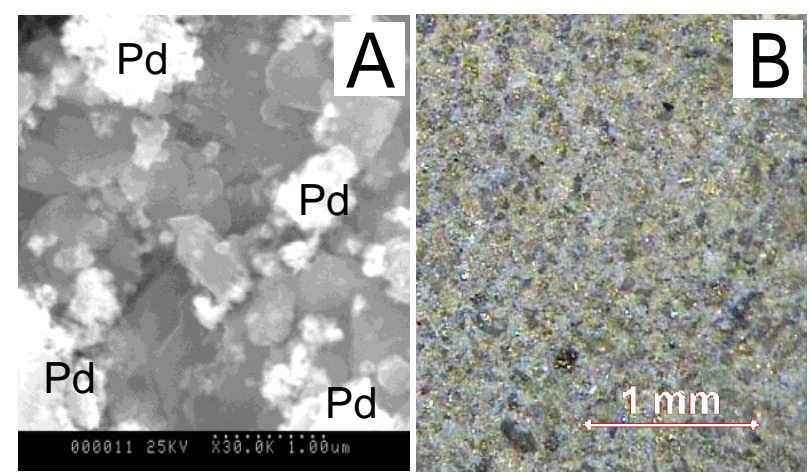

Fig. 2 


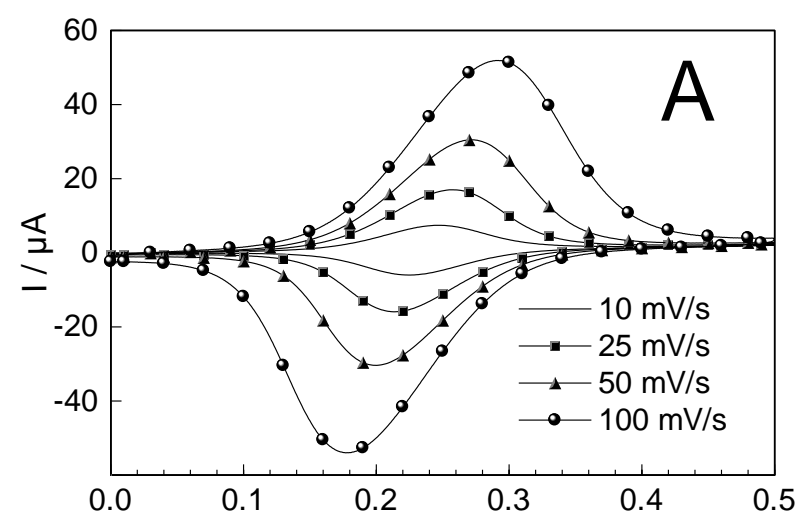

Fig. 3

2

E / V vs. silver wire
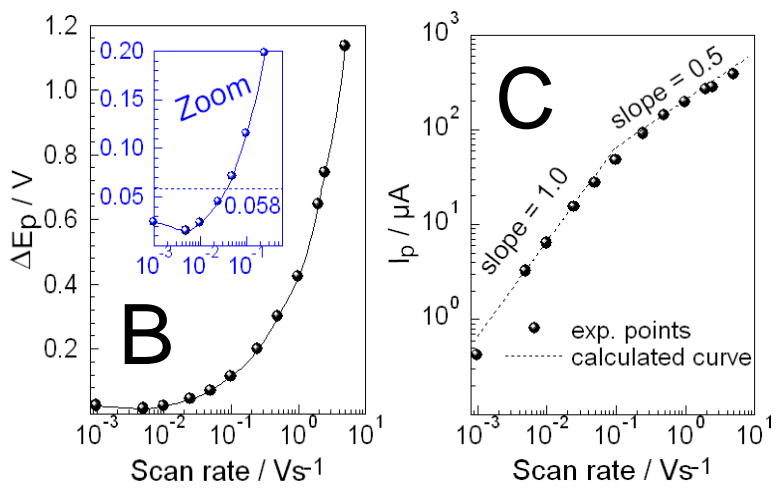

4

6

E / V vs. SHE

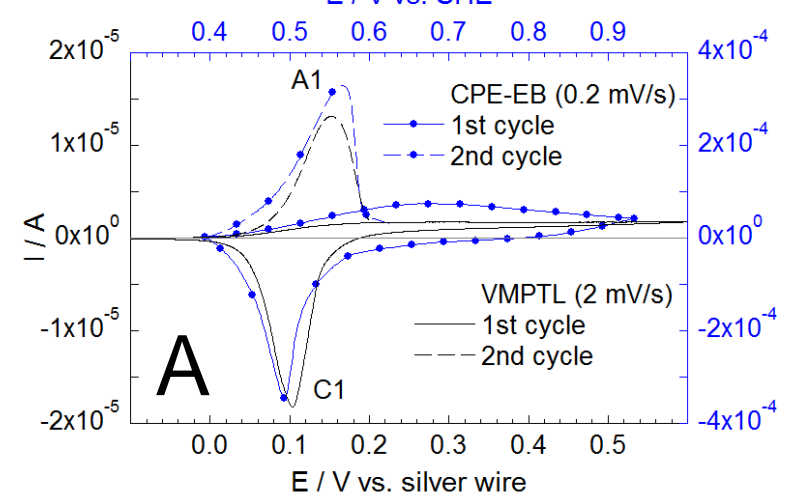

14

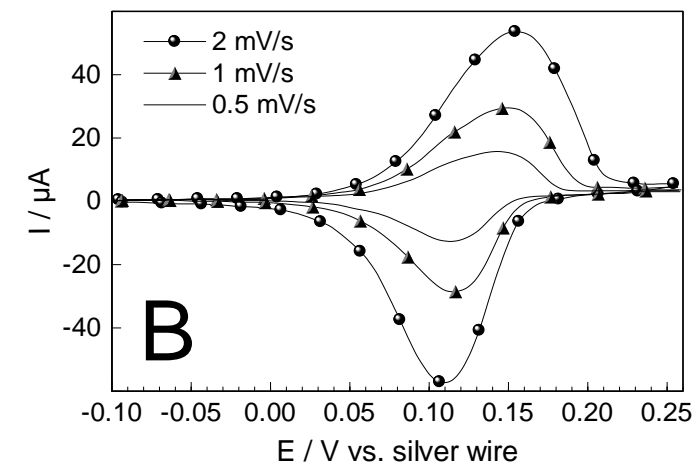




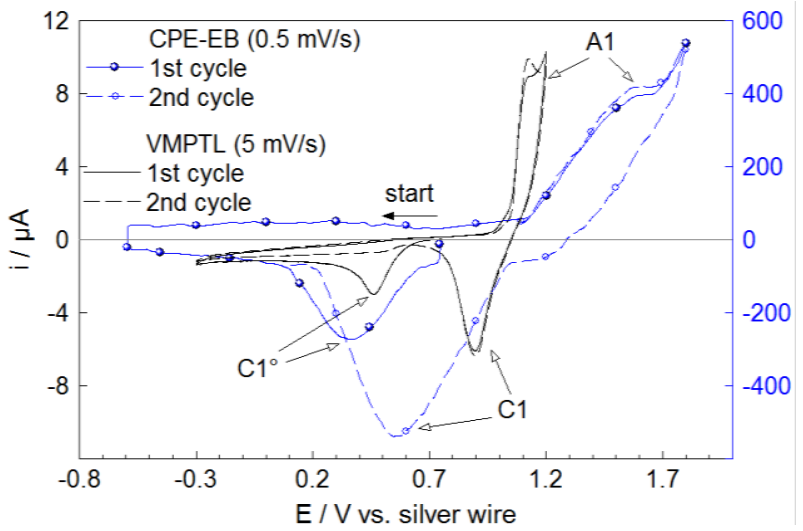

Fig. 5

6

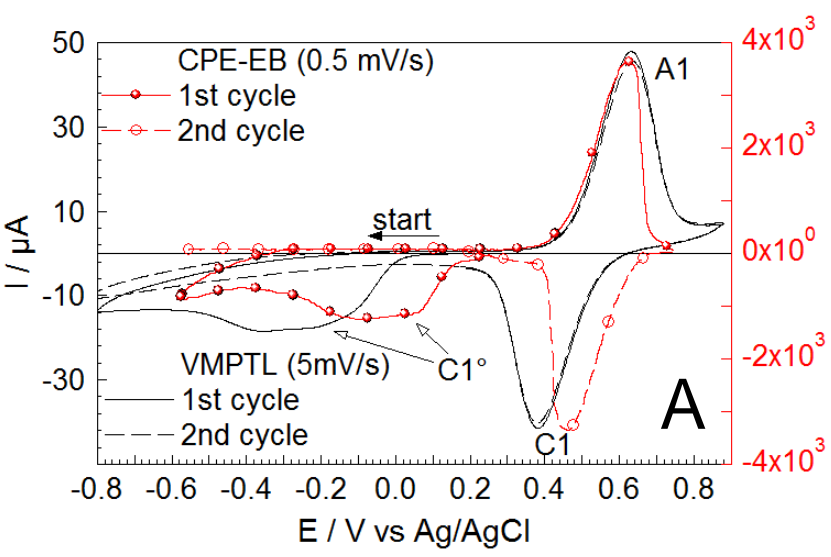

Fig. 6

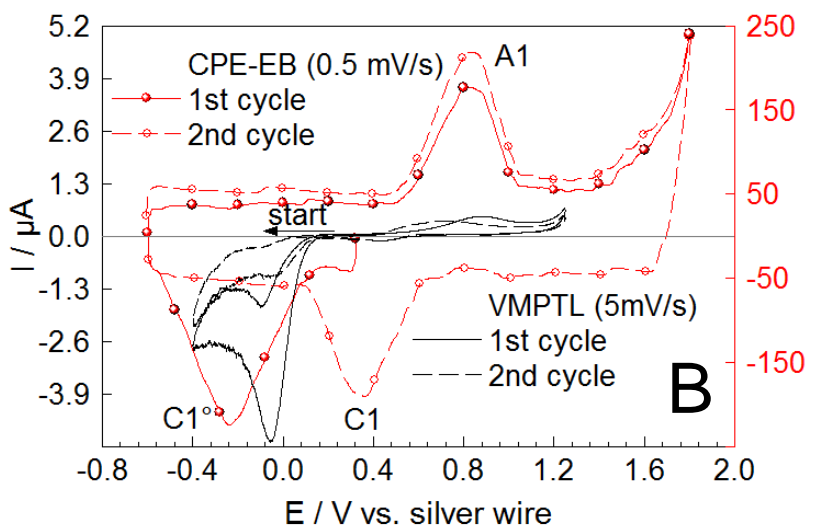

8

$\mathrm{E} / \mathrm{V}$ vs. silver wire

10

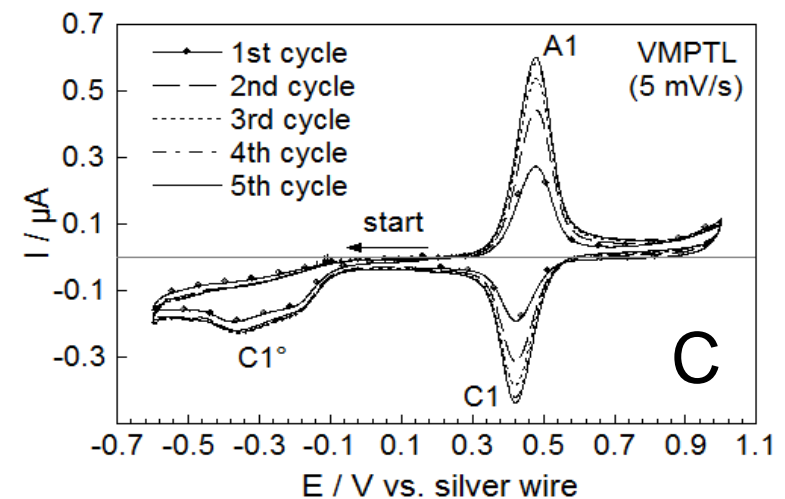


2

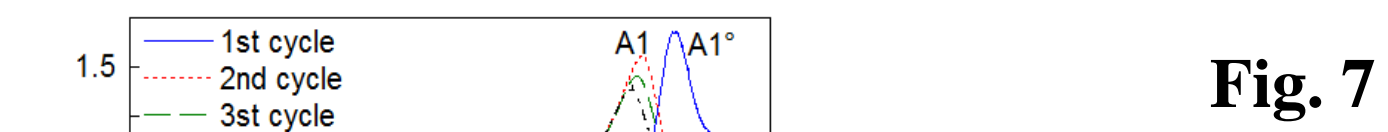

4

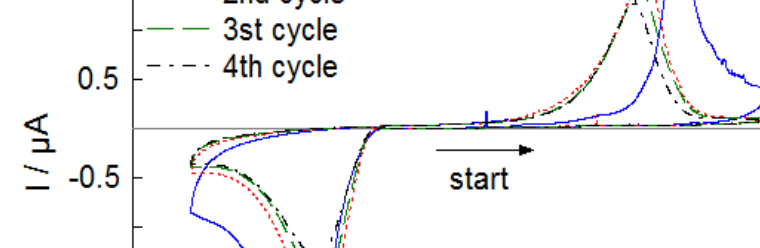

A
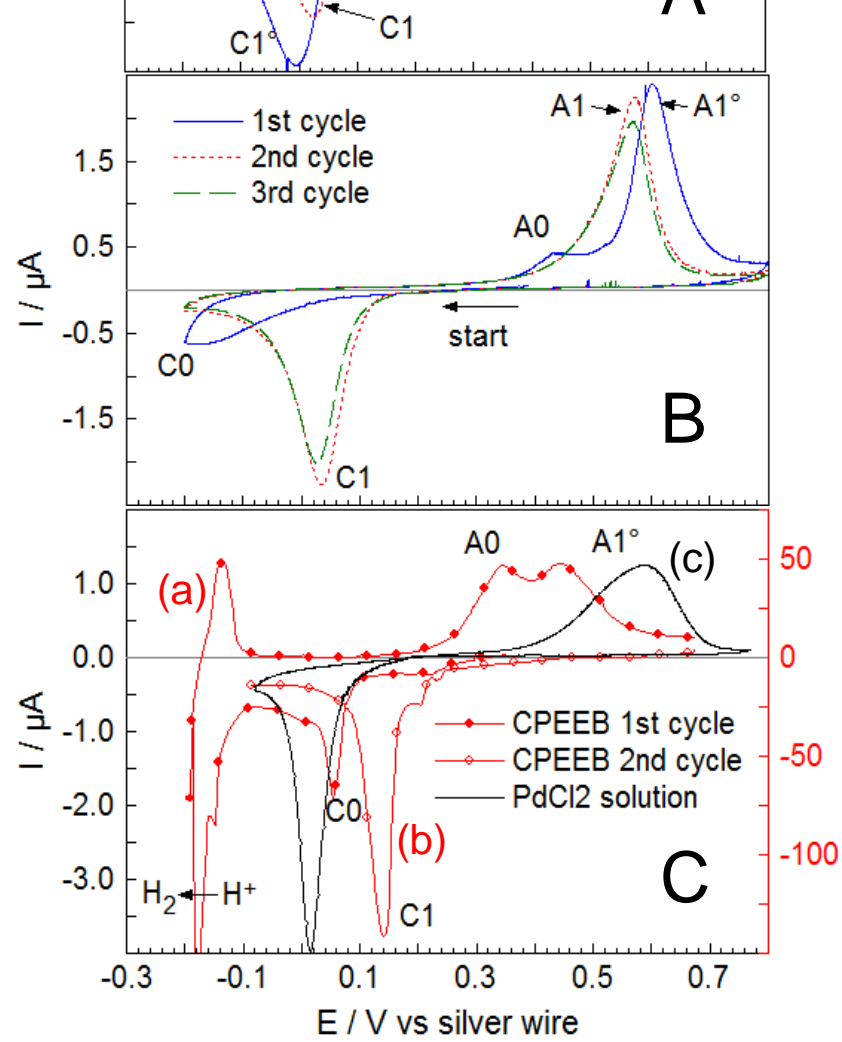

6

$\mathrm{E} / \mathrm{V}$ vs silver wire

10

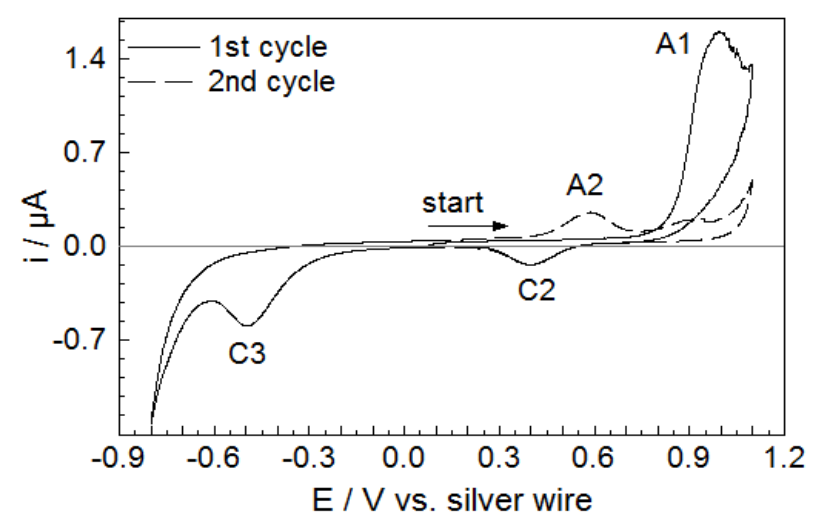

Fig. 8 